\title{
Microbial Contamination of Electrical Power Transformer Oil Obtained from Onitsha, Nigeria
}

\author{
Onuorah Samuel $^{1, *}$, Orji Michael $^{1}$, Obika Ifeanyi $^{2}$ \\ ${ }^{1}$ Department of Applied Microbiology and Brewing, Nnamdi Azikiwe University Awka, Nigeria \\ ${ }^{2}$ Department of Zoology, Nnamdi Azikiwe University Awka, Nigeria
}

Copyright $(2016$ by authors, all rights reserved. Authors agree that this article remains permanently open access under the terms of the Creative Commons Attribution License 4.0 International License

\begin{abstract}
Microbial contamination of in-use and unused electrical power transformer oils obtained from Onitsha, Nigeria was studied using cultural techniques. The average bacterial and fungal counts of the in-use oil were $1.2 \times 10^{2}$ $\mathrm{cfu} / \mathrm{ml}$ and $0.7 \times 10^{2} \mathrm{cfu} / \mathrm{ml}$ respectively while the mean bacterial and fungal counts of the unused oil were $0.5 \times 10^{2}$ $\mathrm{cfu} / \mathrm{ml}$ and $0.3 \mathrm{x} 10^{2} \mathrm{cfu} / \mathrm{ml}$ respectively. The microorganisms from the in-use oil were Micrococcus luteus, Pseudomonas aeruginosa, Serratia marcescens, Corynebacterium bovis, Bacillus subtilis, Klebsiella aerogenes, Aspergillus niger, Aspergillus flavus and Mucor pusillus while those from the unused oil were Micrococcus luteus, Serratia marcescens, Bacillus subtilis, Klebsiella aerogenes and Aspergillus fumigatus. Bacillus subtilis occurred most frequently in both oils. The $\mathrm{P}^{\mathrm{H}}$ of the medium decreased to the acidic level while there was an increase in the viable counts, indicating the utilization of the transformer oils by the isolates. These isolates may cause the deterioration in the oils quality leading to the failure of the transformer with its attendant economic losses. Regular inspection and maintenance of the transformer as well as periodic changing of its oil is recommended to curb the economic losses.
\end{abstract}

Keywords Microorganisms, Contamination, Transformer, Oil, Nigeria

\section{Introduction}

An electrical power transformer is a static device which transforms electrical energy from one circuit to another without any direct electrical connection and with the help of mutual induction between two windings. It transforms power from one circuit to another without changing its frequency but may be in a different voltage level [1].

Transformer oil also known as mineral insulating oil is normally obtained by fractional distillation and subsequent treatment of crude petroleum. It provides liquid insulation and dissipates the heat generated by the transformer. It is subject to electrical and mechanical stresses while a transformer is in operation. In addition, there is contamination caused by chemical interactions with windings and other solid insulations catalyzed by high operating temperature leading to gradual changes in the original chemical properties of the oil and microbial growth thus gradually rendering it ineffective for its intended purpose [2].

Microorganisms have been reported to have adverse effects on in-use lubricating oil. These organisms include the Pseudomonads, Yeasts, Moulds and the anaerobic sulphate-reducing bacteria [3, 4]. Microbial occurrence in in-use lubricating oil may result in the reduction of its $\mathrm{P}^{\mathrm{H}}$, increased corrosiveness, depletion of the important components, reduction in efficiency and the failure of engines [5], therefore this work reported the isolation, characterization and identification of the microbial contaminants in the electrical power transformer oil obtained from Onitsha, Nigeria and their ability to grow and utilize the oil as sole source of carbon and energy.

\section{Materials and Methods}

\subsection{Samples Collection}

Ten samples of in-use electrical power transformer oil were collected from step-down transformers in various locations in Onitsha, Nigeria into sterile screw-capped bottles. The oils had been in the transformers for five years. The un-used oil samples (ten in number) were obtained from an electrical power distribution company at Onitsha, Nigeria.

\subsection{Samples Processing}

Drops of each of the samples (in-use and unused) were introduced into sterile flasks containing sterile nutrient broth and incubated at $28^{0} \mathrm{C}$ for twenty-four hours. Ten-fold serial dilutions of the samples were made using physiological saline. 


\subsection{Bacterial Isolation}

$0.1 \mathrm{ml}$ of each of the serially-diluted samples $\left(10^{2}\right)$ was spread-plated on sterile nutrient agar (NA) plates containing Ketoconazole at a concentration of $0.05 \mathrm{mg} / \mathrm{ml}$ to inhibit fungal growth. The plates were incubated at $28^{\circ} \mathrm{C}$ for forty-eight hours after which the bacterial colonies that developed were counted, purified by repeated subculturing on sterile NA plates and later stored on sterile NA slants for characterization and identification.

\subsection{Fungal Isolation}

$0.1 \mathrm{ml}$ of each of the serially-diluted samples $\left(10^{2}\right)$ were introduced into sterile plates of sabouraud dextrose agar (SDA) and evenly spread with a sterile wire loop. The plates also had chloramphenicol at a concentration of $0.05 \mathrm{mg} / \mathrm{ml}$ to inhibit bacterial growth. Incubation was carried out at $28^{0} \mathrm{C}$ for seventy-two hours after which the fungal colonies that grew were counted, subscultured repeatedly on sterile SDA plates and stored on sterile SDA slants for identification tests.

\subsection{Characterization and Identification of the Bacterial Isolates}

The bacterial isolates were characterized morphologically and biochemically. Gram staining, catalase, spore, methyl red, voges proskaeur, citrate utilization, oxidase, indole, nitrate reduction, motility and sugar (sucrose, glucose, fructose, and galactose) fermentation tests were carried out as done by Onuorah et al [6]. They were identified as described by Holt et al [7].

\subsection{Characterization and Identification of the Fungal Isolates}

The fungal isolates were characterized using the slide culture and lactophenol cotton blue dye tests as done by Onuorah et al [8]. They were identified as described by Oyeleke and Manga [9].

\subsubsection{Slide Culture Test}

A small portion of the test fungus was inoculated on a slide containing prepared sabouraud dextrose agar using a sterile inoculating wire. The slide was incubated at $28^{\circ} \mathrm{C}$ for 24 hours, stained with lactophenol cotton blue solution and viewed under the microscope.

\subsubsection{Lactophenol Cotton Blue Dye Test}

A drop of the lactophenol cotton blue dye was placed on a slide and a small portion of the test fungus emulsified in it. The slide was thereafter covered with a coverslip, avoiding bubbles and viewed under the microscope.

\subsection{Growth Profile of the Microorganisms in the Transformer Oils}

The method of Okpokwasili and Okorie [5] was used.
Mineral salts medium of Mills et al [10] was used as the growth medium. It was prepared and dispensed in $9.9 \mathrm{ml}$ amounts into twenty test tubes. Half of the tubes had $0.1 \mathrm{ml}$ of the in-use oil while the other half had $0.1 \mathrm{ml}$ of the unused oil. The test tubes were capped, sterilized by autoclaving at $121^{\circ} \mathrm{C}$ for fifteen minutes and allowed to cool, after which the microorganisms were inoculated into them individually. Uninoculated tubes served as controls. The test tubes were incubated at $28^{\circ} \mathrm{C}$ in a rotary shaker for twenty-eight days after which the final $\mathrm{P}^{\mathrm{H}}$ of the medium and the final viable counts were determined. The initial $\mathrm{P}^{\mathrm{H}}$ and viable counts were determined before the inoculation and at inoculation respectively.

\subsubsection{Determination of the $\mathrm{P}^{\mathrm{H}}$ of the Medium}

The $\mathrm{P}^{\mathrm{H}}$ of the mineral salts oil medium was determined before inoculation and at the end of the incubation with a $\mathrm{P}^{\mathrm{H}}$ meter (JENWAY) that was standardized with phosphate buffers. The electrode of the meter was inserted into the tubes containing the medium and the $\mathrm{P}^{\mathrm{H}}$ value read and recorded.

\subsubsection{Determination of the Viable Counts}

The viable counts were determined at inoculation and at the end of the experiment using the spread plate technique. Mineral salts agar of Mills et al [10] served as the culture medium. 0.1 millilitre of the content of each test tube was spread-plated on the surface of the medium using a sterile wire loop. The plates were thereafter incubated at $28^{\circ} \mathrm{C}$ for 48 hours for bacteria and 72 hours for fungi, after which the microbial colonies that developed were counted and the values recorded.

\section{Results}

The microbial counts of the in-use electrical power transformer oil are shown in Table 1. The bacterial counts ranged between $0.7 \times 10^{2} \mathrm{cfu} / \mathrm{ml}$ and $1.7 \times 10^{2} \mathrm{cfu} / \mathrm{ml}$ while the fungal counts were between $0.3 \times 10^{2} \mathrm{cfu} / \mathrm{ml}$ and $1.2 \mathrm{x}$ $10^{2} \mathrm{cfu} / \mathrm{ml}$. microorganisms were isolated from all the in-use samples examined. The mean bacterial count was $1.2 \times 10^{2}$ $\mathrm{cfu} / \mathrm{ml}$ while the mean fungal count was $0.7 \times 10^{2} \mathrm{cfu} / \mathrm{ml}$.

Table 1. Microbial Counts of the In-Use Electrical Power Transformer Oil

\begin{tabular}{ccc}
\hline Sample & $\begin{array}{c}\text { Bacterial Counts }\left(\mathrm{x} 10^{2}\right. \\
\mathrm{cfu} / \mathrm{ml})\end{array}$ & $\begin{array}{c}\text { Fungal Counts }\left(\mathrm{x} 10^{2}\right. \\
\mathrm{cfu} / \mathrm{ml})\end{array}$ \\
\hline 1 & 1.0 & 0.6 \\
2 & 1.3 & 0.7 \\
3 & 1.4 & 0.8 \\
4 & 1.6 & 1.0 \\
5 & 1.7 & 1.2 \\
6 & 0.8 & 0.5 \\
7 & 0.9 & 0.4 \\
8 & 1.1 & 0.6 \\
9 & 1.5 & 0.9 \\
10 & 0.7 & 0.3 \\
Mean & 1.2 & 0.7 \\
\hline
\end{tabular}


The microbial counts of the unused oil are presented in Table 2. All the unused samples examined were contaminated with microorganisms. The bacterial counts were between $0.1 \times 10^{2} \mathrm{cfu} / \mathrm{ml}$ and $0.9 \times 10^{2} \mathrm{cfu} / \mathrm{ml}$ while the fungal counts ranged between $0.1 \times 10^{2} \mathrm{cfu} / \mathrm{ml}$ and $0.6 \times 10^{2}$ $\mathrm{cfu} / \mathrm{ml}$ The average bacterial counts was $0.5 \times 10^{2} \mathrm{cfu} / \mathrm{ml}$ while the mean fungal count was $0.3 \times 10^{2} \mathrm{cfu} / \mathrm{ml}$.

Table 2. Microbial Counts of the Unused Electrical Power Transformer Oil

\begin{tabular}{ccc}
\hline Sample & $\begin{array}{r}\text { Bacterial Counts }\left(\mathrm{x} 10^{2}\right. \\
\text { cfu/ml })\end{array}$ & $\begin{array}{r}\text { Fungal Counts }\left(\mathrm{x} 10^{2}\right. \\
\mathrm{cfu} / \mathrm{ml})\end{array}$ \\
\hline 1 & 0.2 & 0.1 \\
2 & 0.5 & 0.2 \\
3 & 0.6 & 0.5 \\
4 & 0.8 & 0.4 \\
5 & 0.9 & 0.6 \\
6 & 0.2 & 0.1 \\
7 & 0.4 & 0.3 \\
8 & 0.3 & 0.2 \\
9 & 0.9 & 0.5 \\
10 & 0.1 & 0.1 \\
Mean & 0.5 & 0.3 \\
\hline
\end{tabular}

The microorganisms isolated from the electrical power transformer oils are shown in Table 3. They were Micrococcus luteus, Pseudomonas aeruginosa, Serratia marcescens, Corynebacterium bovis, Bacillus subtilis, Klebsiella aerogenes, Aspergillus niger, Aspergillus flavus, Mucor pusillus and Aspergillus fumigatus.

Table 3. Microorganisms Isolated from the Electrical Power Transformer Oils

\begin{tabular}{ccc}
\hline Organisms & In-Use Oil & Unused Oil \\
\hline Micrococcus luteus & + & + \\
Pseudomonas aeruginosa & + & - \\
Serratia marcescens & + & + \\
Corynebacterium bovis & + & - \\
Bacillus subtilis & + & + \\
Klebsiella aerogenes & + & + \\
Aspergillus niger & + & + \\
Aspergillus flavus & + & - \\
Mucor pusillus & + & - \\
Aspergillus fumigatus & - & + \\
\hline$=$ detected & &
\end{tabular}

The distribution of the bacterial isolates in the electrical power transformer oils is shown in Table $4.71 .42 \%$ of the isolates occurred in the in-use oil while $28.58 \%$ were isolated from the unused oil. The gram positive bacterium Bacillus subtilis had the highest percentage distribution of $35.71 \%$ and $14.29 \%$ in both the in-use and unused oils respectively.

Table 4. Distribution of the Bacterial Isolates in the Electrical Power Transformer Oils

\begin{tabular}{ccc}
\hline Bacterial Isolates & $\begin{array}{c}\text { \% Distribution } \\
\text { In in-used oil }\end{array}$ & $\begin{array}{c}\text { \% Distribution } \\
\text { in unused oil }\end{array}$ \\
\hline Micrococcus luteus & 14.29 & 8.57 \\
Pseudomonas aeruginosa & 4.28 & 0.00 \\
Serratia marcescens & 5.71 & 2.86 \\
Corynebacterium bovis & 2.86 & 0.00 \\
Bacillus subtilis & 35.71 & 14.29 \\
Klebsiella aerogenes & 8.57 & 2.86 \\
Total & 71.42 & 28.58
\end{tabular}

The distribution of the fungal isolates in the electrical power transformer oils is presented in Table $5.75 .0 \%$ of the fungi were detected in the in-use oil while $25.0 \%$ were isolated from the unused oil. Aspergillus niger had the highest percentage distribution of $37.5 \%$ and $10.0 \%$ in both the in-use and unused oils in both oils.

Table 5. Distribution of the Fungal Isolates in the Electrical Power Transformer Oils

\begin{tabular}{ccc}
\hline Fungal Isolates & $\begin{array}{c}\text { \% Distribution } \\
\text { In in-use oil }\end{array}$ & $\begin{array}{c}\text { \% Distribution } \\
\text { In unused oil }\end{array}$ \\
\hline Aspergillus niger & 37.5 & 10.0 \\
Aspergillus flavus & 15.0 & 5.0 \\
Aspergillus fumigatus & 10.0 & 2.5 \\
Mucor pusillus & 12.5 & 7.5 \\
Total & 75.0 & 25.0 \\
\hline
\end{tabular}

The growth profile of the microorganisms in the in-use electrical power transformer oil is presented in Table 6 . The organisms grew well in the oil as shown by a decrease in the $\mathrm{P}^{\mathrm{H}}$ and substantial increase in the viable counts.

The initial ${ }_{\mathrm{PH}}$ of the medium was 7.2 but the final ${ }_{\mathrm{P}} \mathrm{H}$ ranged between 6.0 and 6.8. The initial viable counts ranged between $0.1 \times 10^{2} \mathrm{cfu} / \mathrm{ml}$ and $0.8 \times 10^{2} \mathrm{cfu} / \mathrm{ml}$ while the final viable counts were between $3.0 \times 10^{2} \mathrm{cfu} / \mathrm{ml}$ and $9.0 \times 10^{2}$ $\mathrm{cfu} / \mathrm{ml}$.

Table 6. Growth Profile of the Microorganisms in the In-Use Electrical Power Transformer Oil

\begin{tabular}{|c|c|c|c|c|}
\hline Microorganisms & Initial $\mathrm{P}^{\mathrm{H}}$ & Final $\mathrm{P}^{\mathrm{H}}$ & Initial Viable Counts $\left(\times 10^{2} \mathrm{cfu} / \mathrm{ml}\right)$ & Final Viable Counts $\left(\times 10^{2} \mathrm{cfu} / \mathrm{ml}\right)$ \\
\hline Micrococcus luteus & 7.2 & 6.1 & 0.6 & 7.0 \\
\hline Pseudomonas aeruginosa & 7.2 & 6.3 & 0.2 & 4.8 \\
\hline Serratia marcescens & 7.2 & 6.3 & 0.3 & 5.2 \\
\hline Corynebacterium bovis & 7.2 & 6.8 & 0.1 & 4.0 \\
\hline Bacillus subtilis & 7.2 & 6.0 & 0.8 & 9.0 \\
\hline Klebsiella aerogenes & 7.2 & 6.4 & 0.6 & 6.8 \\
\hline Aspergillus flavus & 7.2 & 6.6 & 0.5 & 3.7 \\
\hline Mucor pusillus & 7.2 & 6.4 & 0.4 & 4.2 \\
\hline Aspergillus fumigatus & 7.2 & 6.8 & 0.2 & 3.0 \\
\hline
\end{tabular}


Table 7. Growth Profile of the Microorganisms in the Unused Electrical Power Transformer Oil

\begin{tabular}{ccccc}
\hline Microorganisms & Initial $\mathrm{P}^{\mathrm{H}}$ & Final $\mathrm{P}^{\mathrm{H}}$ & $\begin{array}{c}\text { Initial Viable Counts }\left(10^{2}\right. \\
\text { cfu/ml })\end{array}$ & $\begin{array}{c}\text { Final Viable Counts } \\
\left(10^{2} \mathrm{cfu} / \mathrm{ml}\right)\end{array}$ \\
\hline Micrococcus luteus & 7.2 & 6.5 & 0.7 & 4.2 \\
Pseudomonas aeruginosa & 7.2 & 6.6 & 0.2 & 2.7 \\
Serratia marcescens & 7.2 & 6.6 & 0.4 & 3.4 \\
Corynebacterium bovis & 7.2 & 7.0 & 0.2 & 2.5 \\
Bacillus subtilis & 7.2 & 6.4 & 0.6 & 6.5 \\
Klebsiella aerogenes & 7.2 & 6.7 & 0.4 & 3.8 \\
Aspergillus niger & 7.2 & 6.5 & 0.8 & 3.6 \\
Aspergillus flavus & 7.2 & 6.8 & 0.3 & 3.0 \\
Mucor pusillus & 7.2 & 6.6 & 0.5 & 3.3 \\
Aspergillus fumigatus & 7.2 & 7.0 & 0.1 & 2.4 \\
\hline
\end{tabular}

The growth profile of the microorganisms in the unused electrical power transformer oil is shown in Table 7. The organisms also grew in the oil though their growth rate was more in the in-use oil. The initial ${ }_{\mathrm{PH}} \mathrm{H}$ of the medium was also 7.2 but the final ${ }_{\mathrm{P}} \mathrm{H}$ values were between 6.4 and 7.0. The initial viable counts were between $0.1 \times 10^{2} \mathrm{cfu} / \mathrm{ml}$ and $0.8 \mathrm{x}$ $10^{2} \mathrm{cfu} / \mathrm{ml}$ while the final viable counts ranged between $2.4 \mathrm{x}$ $10^{2} \mathrm{cfu} / \mathrm{ml}$ and $6.5 \times 10^{2} \mathrm{cfu} / \mathrm{ml}$.

\section{Discussion}

The mean bacterial and fungal counts of the in-use electrical power transformer oil were $1.2 \times 10^{2} \mathrm{cfu} / \mathrm{ml}$ and $0.7 \times 10 \mathrm{cful} / \mathrm{ml}$ respectively (Table 1 ). The bacterial population was more than the fungi in the oil. The average bacterial count of the unused oil was $0.5 \times 10^{2} \mathrm{cfu} / \mathrm{ml}$ while that of the fungi was $0.3 \times 10^{2} \mathrm{cful} / \mathrm{ml}$ (Table 2). The population of microorganisms was more in the in-use than in the unused oil.

Ten species of microorganisms were isolated from the electrical power transformer oils. They were Micrococcus luteus, Pseudomonas aeruginosa, Serratia marcescens, Corynebacterium bovis, Bacillus subtilis,Klebsiella gerogenes, Aspergillus niger, Aspergillus flavus, Mucor pusillus and Aspergillus fumigatus. More organisms were isolated from the in-use oil than the unused oil. More bacteria were also isolated from the in-use oil than the unused oil (Table 3). This result agreed with the work of Okpokwasili and Okorie [5] on the biodeterioration potentials of microorganisms isolated from car engine lubricating oil. They isolated most of these organisms in their car engine lubricating oil and reported that more bacteria were isolated from the in-use car engine lubricating oil than the unused one.

Bacillus subtilis was the predominant bacteria isolated from both the in-use and unused transformer oils. More gram positive bacteria were also isolated from the oils than the gram negative bacteria (Table 4). The predominance of Bacillus subtilis may be attributed to the fact that it is a spore former and is thus resistant to the heat of the in-use oil as well as the biocides in the unused oil. This result is in agreement with the report of Okpokwasili and Okorie [5] about the preponderance of gram positive bacteria particularly Bacillus $s p$ in car engine lubricating oil.

Aspergillus niger was the predominant fungus isolated from both the in-use and unused transformer oils (Table 5). This may be because of the ubiquitous nature of this fungus and its ability to produce heat resistant spores. The genus Aspergilli also outnumbered the other fungal isolates.

The microbial isolates grew in the in-use and unused oils utilizing the hydrocarbons as source of carbon and energy. There was a drop in the $\mathrm{P}^{\mathrm{H}}$ of the mineral salts-oil medium and an increase in the viable counts of the organisms as they grew in both oils (Tables 6 and 7). The organisms probably produced organic acids during their growth in such oils. The production of such acids may have been responsible for the drop in the $\mathrm{P}^{\mathrm{H}}$ from the alkaline to the slightly acidic level.

The decrease in the $\mathrm{P}^{\mathrm{H}}$ and the increase in viable counts were more pronounced in the in-use than the unused oil. This may be due to the fact that the unused oil contains some biocides which may have adversely affected the growth of the organisms in the oil. This result conformed to the reports of Okpokwasili and Okorie [5] and Okpokwasili and James [3].

In-use oil supported the growth of the microbial isolates more than the unused one. This may be as a result of the metabolites produced by the microorganisms while the oil was in service which supported their growth. The bacterial isolates utilized the in-use and unused transformer oil better than the fungal isolates indicating that the bacteria are the major organisms responsible for the deterioration in the quality of transformer oil. The contamination of the transformer oil may have come from the air, handlers, containers, soil and water.

This work indicated that the microorganisms in the transformer oils are bacteria and fungi and that in-use oil is a better substrate for their growth than the unused one. Though these organisms in the oils have been known to be useful in the degradation of toxic carbon compounds, they can 
adversely affect the quality of transformer oil eventually leading to friction and the failure of the transformer, with the attendant cost of replacement, therefore regular maintenance of the transformer and periodic changing of its oil will eliminate these problems.

\section{Conclusions}

Electrical power transformer oil is prone to deterioration as a result of the growth and activities of microorganisms such as bacteria and fungi in it. The deterioration may adversely affect the quality of such oil leading to friction between the essential parts, transformer failure, power outage and economic losses due to replacement. Transformers should therefore undergo regular inspection and maintenance including the changing of its oil periodically to curb these problems.

\section{REFERENCES}

[1] M. W. Anyakorah. New School Physics for Senior Secondary Schools (SS1 - SS3). Africana - FEP Publishers Limited, Onitsha, Pp 436 - 438, 2000.

[2] K. R. Edwards. Transformers. American Technical Publishers Limited, Pp 138 - 140, 1996.

[3] G.S.C. Okpokwasili, W.A. James. Microbial Contamination of
Kerosene, gasoline and crude oil and their spoilage potentials. Materials and Organismen, Vol. 29, 147 - 156, 1995.

[4] K. W. Yedder, H. W Rossmoore. The detection of airborne sulfate - reducing bacteria from metal working fluid. Biodeterioration, Vol. 6, 459-469, 1986.

[5] G. S. C. Okpokwasili, B. B. Okorie. Biodeterioration potentials of microorganisms isolated from car engine lubricating oil. Tribology International, Vol. 21, No. 4, 215 220, 1988. Doi: 10.1016/0301-679x(88)90020-5.

[6] S. Onuorah, I. Obika, M. Orji, F. Odibo. Microbial Contaminants in the Commercial aviation fuel obtained from Benin City airport, Nigeria. Universal Journal of Microbiology Research, Vol. 3, No.3, 31-35, 2015.Doi:10.13189/ujmr.2015.030301.

[7] J. G. Holt, N. R. Krieg, P. H. A. Sneath, T. W. Staley. Bergey's manual of determinative bacteriology. $9^{\text {th }}$ edition, Williams and Wilkins Company, New York, U.S.A. Pp 817-825, 1994.

[8] S. Onuorah, I. Obika, U. Okafor. Filamentous fungi associated with the spoilage of post-harvest sweet orange fruits (Citrus sinensis) sold in Awka major markets, Nigeria. Bioengineering and Bioscience, Vol. 3, No. 3, 44-49, 2015. Doi: $10.13189 /$ bb.2015.030303.

[9] S. B. Oyeleke, S. B. Manga. Essentials of laboratory practical in Microbiology. To best Publishers, Minna, Nigeria. Pp36-75, 2008

[10] A.L. Mills, C. Breuil, R. R. Colwell. Enumeration of Petroleum degrading marine and estuarine microorganisms by the most probable number method. Canadian Journal of Microbiology, Vol. 24, No. 5, 552 - 557, 1978. Doi: 10.1139/m78-089. 